\title{
Study of the stability of passion fruit (Passiflora edullis f. flavicarpa) powder from organic farming
}

\section{Estabilidade maracujá (Passiflora edullis f. flavicarpa) em pó oriundo do cultivo orgânico}

\author{
Juliana Nascimento da Costa ${ }^{1 *}$; Raimundo Wilane de Figueiredo ${ }^{2}$; \\ Paulo Henrique Machado de Sousa ${ }^{3}$; Maria Leonia da Costa Gonzaga ${ }^{4}$; \\ Patricia Beltrão Lessa Constant ${ }^{5}$; Denise Josino Soares ${ }^{6}$
}

\begin{abstract}
Passion fruit is a fruit originating in the American tropics, is cultivated in countries with tropical and subtropical climates and belongs to the Passifloraceae family and Passiflora gender. One of the methods of cultivation of passion fruit is the organic system, a practice increasingly common in order to combine quality of food products with environmental preservation. Considering the current trends for nutritious foods and fast preparation, the use of dehydrated passion fruit offers an interesting alternative to reduce losses, add value to the product and provide other ways to consume fruit. Based on this information, the objective was to evaluate the stability and the quality of the organic passion fruit powder, obtained by spray drying, during 360 days of storage under room temperature $\left(25 \pm 2{ }^{\circ} \mathrm{C}\right)$. The passion fruit powder was evaluated every 30 days during the 360 days of storage, for the chemical, physic-chemical and microbiological parameters. The organic passion fruit powder remained stable during the 360 days of storage at room temperature, offering great potential for use due to present adequate retention of ascorbic acid $(15.86 \mathrm{mg} / 100 \mathrm{~g})$, desired hygroscopicity (22.71 $\mathrm{g}$ of absorbed water/100 g), low water activity (0.47), stable acid $\mathrm{pH}(4.16)$, high levels of ash (4.77\%), total sugar (36.94\%), total extractable polyphenols (196.17 mg GAE/100 g) and satisfactory microbiological results with absence of coliforms at $35^{\circ} \mathrm{C}$ and $45^{\circ} \mathrm{C}$, Salmonella sp $/ 25 \mathrm{~g}$, mesophilic and Staphylococcus coagulase positive values were less than $10 \mathrm{CFU} / \mathrm{g}$.
\end{abstract}

Key words: Passion fruit, spray drying, stability, organic cultivation

\section{Resumo}

O maracujá é um fruto originário da América Tropical, sendo cultivado em países de climas tropical e subtropical, pertencente à família Passifloraceae, gênero Passiflora. Dentre os métodos de cultivo do maracujá, tem-se a produção pelo sistema orgânico, uma prática cada vez mais comum, visando aliar qualidade de produtos alimentícios com a preservação ambiental. Considerando as tendências atuais por alimentos nutritivos e de rápido preparo, o uso do maracujá sob a forma desidratada, consiste em uma interessante alternativa para a redução de perdas, agregar valor ao produto e proporcionar

\footnotetext{
${ }^{1}$ Mestre em Ciência e Tecnologia de Alimentos, Universidade Federal do Ceará, UFC, Fortaleza, CE. E-mail: julianacosta31@ gmail.com

${ }^{2}$ Prof. Dr. do Dept ${ }^{\mathrm{o}}$ de Tecnologia de Alimentos, UFC, Fortaleza, CE. E-mail: figueira@ufc.br

${ }^{3}$ Prof. Dr. do Instituto de Cultura e Arte, UFC, Fortaleza, CE. E-mail: phenriquemachado@gmail.com

${ }^{4}$ Pós-Doutoranda do Dept ${ }^{\circ}$ de Tecnologia de Alimentos, UFC, Fortaleza, CE. E-mail: leonia_gonzaga@yahoo.com.br

${ }^{5}$ Prof $^{\mathrm{a}} \mathrm{Dr}^{\mathrm{a}}$ do Dept ${ }^{\mathrm{o}}$ de Tecnologia de Alimentos, Universidade Federal de Sergipe, UFS, Aracaju, SE. E-mail: pblconstant@yahoo. com.br

${ }^{6}$ Discente do Curso de Doutorado em Ciência e Tecnologia de Alimentos, UFC, Fortaleza, CE. E-mail: denisejosino@hotmail.com

* Author for corespondence
} 
outras maneiras de consumo da fruta. Com base nessas informações, o objetivo do trabalho foi avaliar a estabilidade do pó de maracujá amarelo, proveniente de cultivo orgânico, obtido por spray drying, durante armazenamento por 360 dias, sob temperatura ambiente $\left(25 \pm 2{ }^{\circ} \mathrm{C}\right)$. Os pós de maracujá foram avaliados a cada 30 dias, durante 360 dias de armazenamento, quanto aos seguintes parâmetros: químicos, físico-químicos e microbiológicos. O pó de maracujá orgânico manteve-se praticamente estável durante os 360 dias de armazenamento à temperatura ambiente, oferecendo um grande potencial de utilização, por apresentar adequada retenção de ácido ascórbico 15,86 mg/100 g, higroscopicidade desejada, 22,71 g de água absorvida/100 g; baixa atividade de água com teores médios de 0,$47 ; \mathrm{pH}$ ácido estável de 4,16, altos teores de cinzas, 4,77\%; açúcares totais com valores médios de 36,94\%; polifenóis extraíveis totais de $196,17 \mathrm{mg}$ EAG/ $100 \mathrm{~g}$ de pó de maracujá e resultados microbiológicos satisfatórios com ausência de coliformes a $35^{\circ} \mathrm{C}$ e $45^{\circ} \mathrm{C}$, Salmonella $s p / 25 \mathrm{~g}$, mesófilos e contagem de Staphylococcus coagulase positiva, foram encontrados valores menores que $10 \mathrm{UFC} / \mathrm{g}$.

Palavras-chave: Maracujá, atomização, estabilidade, cultivo orgânico

\section{Introduction}

Passion fruit is a fruit originating in the American tropics, is cultivated in countries with tropical and subtropical climates and belongs to the Passifloraceae family and Passiflora gender. There are more than 150 native species in Brazil, 60 of which produce fruit that can be utilized directly or indirectly as food. Among the methods of passion fruit cultivation, the organic system stands out. This passion fruit cultivation by organic system is still incipient in Brazil, however, there is already a great demand, especially by the European market, as it is becoming an increasingly common practice and aim to combine quality of food products with environmental preservation (KISHORE et al., 2011). Some studies have reported an increase in the nutritional value of organic fruits mainly in terms of vitamin $\mathrm{C}$ and mineral content (PAGLIARINI, 2006), but there have been no studies on organic passion fruit powder.

Passion fruit (Passiflora edulis) is mainly used for making juice and pulp; it is, however, highly perishable and this makes the postharvest life and the storage of this fruit very difficult. However, such obstacles to preserving food in its natural form can be solved through the use of preservation techniques, one of which is dehydration (BEZERRA, 2009).

Among the different products developed, the powder stands out because its utilization removes the inconvenience of the short shelf life, and makes it possible to keep the material at room temperature, with no costs involved in keeping the cold, low mass/ volume ratio with consequent savings in packaging costs, transport, and storage space, aspects which add value to the product (VIEIRA; FIGUEIRÊDO; QUEIROZ, 2007).

Spray drying is one of the best processes for dehydration of thermosensitive liquids or paste foods, due to the quick food contact at high temperatures, high hourly production and low costs when compared with the freeze drying. It is used in the drying of food due to its low degradation and alteration of nutrients, aroma, flavor and color. It also has high productivity and capacity, an effective control of variables, high energy efficiency, and it produces materials directly in powder form, with shape, size and density control of the process conditions, and it is capable of microencapsulation of the aroma (OLIVEIRA et al., 2007). The properties of food in powder form have to be monitored to ensure the product quality, especially in order to keep the original nutritional feedstock characteristics and the product functional properties, such as solubility and hygroscopicity and the color (PEDRO, 2009).

The importance of the study of passion fruit powder is to find the functional characteristics of this product and encourage its use in the production of new foods, such as yogurts and cookies.

In order to verify the characteristic of organic 
products, this work aimed to evaluate the stability and the quality of organic passion fruit powder, obtained by spray drying, during 360 days of storage at room temperature $\left(25 \pm 2{ }^{\circ} \mathrm{C}\right)$.

\section{Material and Methods}

The study was performed using a sample of passion fruit powder given by an American fruit processing company located in the state of Ceara, Brazil. The company produced the passion fruit powder using yellow passion fruits (Passiflora edulis f. flavicarpa) using organic cultivation methods.

Fruits, at the stage of commercial maturity, were manually collected in the early hours of the day and immediately transported to the processing place where they were processed to separate the pulp. The pulp was standardized (with acidulant and maltodextrin), homogenized, pasteurized (95 $\pm 3^{\circ} \mathrm{C} / 60$ seconds) and cooled down to $80-85^{\circ} \mathrm{C}$. The next step was the drying process which was carried out in the spray dryer system. The spray dryer was operated at $190-195^{\circ} \mathrm{C}$, and at the end of the process was cooled down (by the air inlet) to $30-40^{\circ} \mathrm{C}$. The obtained powder was screened on 40 mesh vibrating screens and was put into plastic bags with a capacity of $100 \mathrm{~g}$ and stored in metal packaging. The storage of the product was performed at a controlled temperature of $25 \pm 2{ }^{\circ} \mathrm{C}$.

Samples were packed in metallic multilayer vacuum packing, stored at room temperature, kept in a dry and airy place and in the absence of light. For the stability study, samples were stored for 360 days, being sampled monthly for chemical, physicalchemical and microbiological analysis. There were 13 packages of each batch of passion fruit powder. All packages were stored in a refrigerator $\left(10^{\circ} \mathrm{C}\right)$ and only one package per batch was opened per month to be analyzed. The other packages remained in the refrigerator and were opened only in the corresponding month of analysis.
The analytical determinations were performed according to the following methods: Soluble solids (SS) were quantified by diluting $1 \mathrm{~g}$ of powder in $10 \mathrm{ml}$ of distilled water, followed by filtration. The filtrate was measured in a digital refratometer, model Reichert AR 200 (TECNAL/USA) with a scale ranging from 0 to $32^{\circ}$ Brix and with an estimated reading to $20^{\circ} \mathrm{C}$, according to IAL (2008). Total acidity (TA) was performed by diluting $0.5 \mathrm{~g}$ of powder in $50 \mathrm{ml}$ of distilled water. The solution obtained was titrated with $\mathrm{NaOH} 0.1 \mathrm{M}$ solution, using phenolphtalein (1\%) as indicator, according to IAL (2008). The SS/TA ratio was obtained by the ratio of these two variables (IAL, 2008). pH was performed by direct reading of the solution $1: 10$ (powder: distilled water) using a potentiometer model 400 A (Quimis/Brazil), according to AOAC (1995). Water activity was measured using the digital analyzer Higrotermo 95. Color was determined by direct reading in colorimeter Chroma Meter, model Konica Minolta spectrophotometer CR 400 (Chroma/Japan) calibrated using white ceramic plate, and the variables measured were $\mathrm{L}^{*}$, $\mathrm{a}^{*}, \mathrm{~b}^{*}$, chroma $\left(\mathrm{c}^{*}\right)$ and hue angle $\left(\mathrm{h}^{*}\right),(\mathrm{BUSCH}$ et al., 2004).

Hygroscopicity was performed according to the method described by Cano-Chauca et al. (2005), with modifications. $1 \mathrm{~g}$ of each sample was weighed in Petri dishes. The Petri dishes were placed in a desiccator containing a saturated solution of $\mathrm{NaCl}$ with a relative humidity of $75.29 \%$. Solubility was performed according to Cano-Chauca et al. (2005), with modifications. $0.25 \mathrm{~g}$ of each sample was weighed and was diluted in $25 \mathrm{ml}$ of distilled water. The solution was centrifuged at $3000 \mathrm{rpm} / 5$ minutes. $20 \mathrm{ml}$ of the supernatant was placed in a Petri dish (the Petri dishes had been previously weighed) which was taken to an oven with air circulation at $105^{\circ} \mathrm{C}$ for $5 \mathrm{~h}$ and then weighed again. The solubility was calculated by the difference in mass.

Moisture was measured weighing $5 \mathrm{~g}$ of powder in a porcelain capsule, followed by the heating in an 
oven up to $121^{\circ} \mathrm{C}$ for $12 \mathrm{~h}$ (IAL, 2008). For the ash determination, $1 \mathrm{~g}$ of powder was heated at $540^{\circ} \mathrm{C}$ for $5 \mathrm{~h}$ in a muffle model 318.2 (Quimis), according to AOAC (1995).

Reducing sugars were determined according to Miller (1959). The results were obtained using a spectrophotometer model UV-1800 (Shimadzu) and the 3,5-dinitro-salicylic acid (DNS) solution. Total soluble sugars were performed using the Antrona method, according to Yemn and Willis (1954). $1 \mathrm{~g}$ of powder was diluted in $10 \mathrm{ml}$ of distilled water, and then $2.5 \mathrm{ml}$ of this solution was taken to carry out a new dilution in $25 \mathrm{ml}$ of ethanol. After the second dilution, $5 \mathrm{ml}$ of the ethanolic solution was diluted in $50 \mathrm{ml}$ of distilled water. The solution was filtered and $50 \mu 1$ of this filtrate was used for the reading.

The ascorbic acid determination was performed by the titrimetric method based on the reduction of the indicator 2,6-dichlorophenolindophenol by the ascorbic acid (IAL, 2008). $\beta$-carotene was measured by the Nagata and Yamashita (1992) method with modifications. $1 \mathrm{~g}$ of powder was diluted in $10 \mathrm{ml}$ of distilled water. $1 \mathrm{ml}$ of this dilution was taken and diluted in $10 \mathrm{ml}$ of the extraction solution of acetone:hexane (4:6) in test tube. The test tube was vortexed for 2 minutes followed by the filtration. The solution was read in a spectrophotometer (Shimadzu, model UV-1800) at $453 \mathrm{~nm}, 505 \mathrm{~nm}$, $645 \mathrm{~nm}$ and $663 \mathrm{~nm}$.

Yellow flavonoids were measured according to Francis (1982). $1 \mathrm{~g}$ of powder was diluted in $25 \mathrm{ml}$ of $\mathrm{HCl}$ :ethanol $(15 \mathrm{ml}$ of $\mathrm{HCl} 1.5 \mathrm{M}$ diluted in $85 \mathrm{ml}$ of ethanol). The solution was kept under refrigeration in the absence of the light for $15 \mathrm{~h}$. After that, the solution was filtered and measured in a spectrophotometer (Shimadzu, model UV1800) at $535 \mathrm{~nm}$. For the quantification of the total chlorophyll, $1 \mathrm{~g}$ of powder was macerated in a mortar with a solution of acetone $80 \%$ for disintegration. The acetone $80 \%$ was added until the complete discoloration of the sample. The final volume of the extract was $25 \mathrm{ml}$ (BRUINSMA,
1963). The absorbance reading in spectrophotometer SHIMADZU brand, model UV-1800 (SHIMADZU ( JAPAN) was made up to $652 \mathrm{~nm}$ half-hour of the beginning of extraction. Total chlorophyll levels were measured in $\mathrm{mg} / 100 \mathrm{~g}$ of sample through the method described by Engel and Poggiani (1991).

The determination of the total extractable polyphenols was performed using the FolinCiocalteu solution and the gallic acid as standard, according to Larrauri, Rupérez and Saura-Calixto (1997).

Microbiological analysis was performed according to American Public Health Association (APHA, 2001). The analyses performed were: counts of total coliforms at $35^{\circ} \mathrm{C}$ and fecal coliforms at $45^{\circ} \mathrm{C}$, using the technique of Most Probable Number (MPN/g) and counts of mold and yeasts (CFU/g) was performed by spreading sour potato agar on the surface (final $\mathrm{pH} 3.5$ ) incubated at $25^{\circ} \mathrm{C}$ for 3 and 5 days.

The experiment was conducted in a completely randomized design with three replications, thirteen storage times $(0,30,60,90,120,150,180,210$, 240, 270, 300, 330 and 360 days). The results were evaluated by the Statistical Analysis System for Windows version 9.1 (SAS, 2006), through regression analysis, verifying the coefficient of determination $\left(\mathrm{R}^{2}\right)$ at $5 \%$ of significance.

\section{Results and Discussion}

Chemical, physical-chemical and bioactive compounds analyses

For the analyzed variables, total acidity, SS/AT, $\mathrm{pH}$, water activity, color coordinates $\mathrm{L}^{*}, \mathrm{~b}^{*}, \mathrm{c}^{*}$, $\mathrm{h}^{*}$, solubility, moisture, ash, reducing sugars, total sugars, $\beta$-carotene, ascorbic acid, yellow flavonoids and total extractable polyphenols significant differences $(p \leq 0.05)$ were observed during the 360 days of storage. Soluble solids, a* coordinate, hygroscopicity and chlorophyll did not present significant differences $(\mathrm{p}>0.05)$ during the storage. 
The models tested (linear, quadratic and cubic) did not adjust to the data of soluble solids, total acidity, SS/AT, pH, color, hygroscopicity, solubility, moisture, ash, reducing sugars, total soluble sugars, ascorbic acid, $\beta$-carotene, yellow flavonoids, total chlorophyll and total extractable polyphenols, The models which adjusted to the data of the other analyses are shown in Figure 1.

Figure 1. Water activity (Aw) of organic passion fruit powder obtained by spray drying stored for 360 days under room temperature $\left(25 \pm 2^{\circ} \mathrm{C}\right)$.

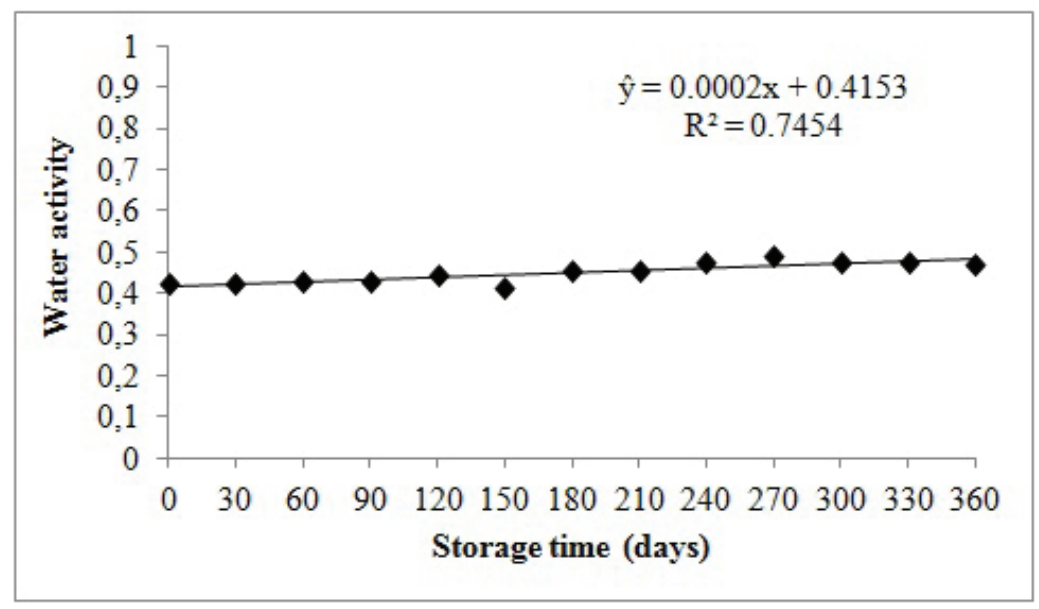

Source: Elaboration of the authors.

The soluble solids values were stable throughout the storage time, with mean values of $89.30^{\circ}$ Brix. This high soluble solids concentration may be related to the maltodextrin presence which was the carrier used in the formulation of the powder. Several authors have attributed the high levels of soluble sugars to the carrier agent type used in the dehydration process, among them maltodrextrin (OLIVEIRA, AFONSO; COSTA, 2011; QUEK, CHOK; SWEDLUND, 2007).

For the titratable acidity, although variation was observed during the storage time. Variations of these values were observed (Table 1), which presented values from $4.69 \mathrm{~g}$ citric acid/100 g to $4.54 \mathrm{~g}$ citric $\mathrm{acid} / 100 \mathrm{~g}$.

The results of SS/TA ranged between 15.63 and 19.84 (Table 1) where the increase was a consequence of the decrease in acidity. The ratio between soluble solids and titratable acidity provides an indication of the flavor of the fruit, because it is related to the amount of sugar and acid present (PRADO, 2009).

Small variations in $\mathrm{pH}$ were observed at the beginning of the storage, however, after 150 days of storage, these results remained practically unchanged, and they stood at 4.16 on the last day of storage (Table 1). Uchoa et al. (2008) studied the passion fruit powder and observed $\mathrm{pH}$ values of 4.17. Canteri et al. (2010) evaluating passion fruit peel flour observed a $\mathrm{pH}$ which ranged from 3.1 to 4.1 .

The results of water activity ranged from 0.42 to 0.47 (Table 1), where the increase can be justified due to the increase in the moisture of passion fruit powder. However, these conditions are considered safe because of the changes in the growth of pathogenic bacteria, since in the low water activity pathogenic bacteria cannot grow. Pedro (2009) observed close values for the passion fruit powder 
with different concentrations of maltodextrin, ranging from 0.18 to 0.20 and verified that there is a change in water activity with the concentration maltodrextrin. Moura (2010) evaluated the stability of acerola powder during 360 days of storage at room temperature and did not observe significance difference $(p>0.05)$ in the water activity during the storage time, obtained mean values of 0.42 .

Table 1. Mean values \pm standard deviation of soluble solids (SS), total acidity (TA), SS/TA, pH, water activity (Aw) and hycroscopicity (Hygrosc.) of passion fruit powder stored at room temperature $\left(25 \pm 2^{\circ} \mathrm{C}\right)$ during 360 days.

\begin{tabular}{ccccccc}
\hline $\begin{array}{c}\text { Time } \\
\text { (days) }\end{array}$ & SS ( ${ }^{\mathbf{0} B r i x)}$ & $\begin{array}{c}\text { TA } \\
\text { (g citric } \\
\text { acid/100 g) }\end{array}$ & SS/TA & pH & Aw & $\begin{array}{c}\text { Hygrosc. } \\
\text { (g absorbed } \\
\text { water/100 g) }\end{array}$ \\
\hline 0 & $93.02 \pm 4.22$ & $4.69 \pm 0.28$ & $19.92 \pm 2.20$ & $4.16 \pm 0.03$ & $0.42 \pm 0.05$ & $22.82 \pm 1.65$ \\
30 & $90.78 \pm 2.68$ & $5.53 \pm 0.16$ & $16.42 \pm 0.99$ & $4.12 \pm 0.04$ & $0.42 \pm 0.03$ & $22.81 \pm 0.95$ \\
60 & $85.25 \pm 2.22$ & $4.97 \pm 0.07$ & $17.14 \pm 0.67$ & $4.13 \pm 0.04$ & $0.42 \pm 0.03$ & $22.54 \pm 0.62$ \\
90 & $90.16 \pm 2.26$ & $5.61 \pm 0.36$ & $16.08 \pm 0.70$ & $4.27 \pm 0.11$ & $0.43 \pm 0.04$ & $24.83 \pm 2.00$ \\
120 & $88.23 \pm 3.53$ & $5.64 \pm 0.11$ & $15.63 \pm 0.60$ & $4.11 \pm 0.02$ & $0.44 \pm 0.03$ & $23.80 \pm 1.57$ \\
150 & $88.88 \pm 4.09$ & $4.95 \pm 0.33$ & $17.95 \pm 0.38$ & $4.19 \pm 0.07$ & $0.41 \pm 0.30$ & $21.30 \pm 1.83$ \\
180 & $87.62 \pm 4.67$ & $4.87 \pm 0.18$ & $17.99 \pm 1.55$ & $4.18 \pm 0.10$ & $0.45 \pm 0.02$ & $21.54 \pm 1.15$ \\
210 & $90.02 \pm 3.23$ & $4.60 \pm 0.21$ & $19.55 \pm 0.40$ & $4.12 \pm 0.01$ & $0.45 \pm 0.01$ & $21.44 \pm 1.12$ \\
240 & $90.21 \pm 4.38$ & $4.54 \pm 0.21$ & $19.84 \pm 0.35$ & $4.21 \pm 0.05$ & $0.47 \pm 0.02$ & $21.83 \pm 0.61$ \\
270 & $89.13 \pm 6.95$ & $5.42 \pm 1.07$ & $16.74 \pm 2.29$ & $4.22 \pm 0.23$ & $0.49 \pm 0.01$ & $21.60 \pm 0.73$ \\
300 & $88.47 \pm 2.03$ & $4.58 \pm 0.22$ & $19.35 \pm 1.19$ & $4.19 \pm 0.33$ & $0.47 \pm 0.04$ & $23.15 \pm 3.48$ \\
330 & $91.76 \pm 2.40$ & $4.95 \pm 0.57$ & $18.63 \pm 1.74$ & $4.28 \pm 0.14$ & $0.47 \pm 0.03$ & $23.78 \pm 4.59$ \\
360 & $88.19 \pm 0.55$ & $4.54 \pm 0.29$ & $19.47 \pm 1.36$ & $4.16 \pm 0.10$ & $0.47 \pm 0.03$ & $22.71 \pm 3.88$ \\
\hline Average & 89.36 & 5.03 & 18.05 & 4.17 & 0.44 & 22.62 \\
\hline
\end{tabular}

Source: Elaboration of the authors.

The hygroscopicity showed mean values of 22.62 $\mathrm{g}$ of absorbed water/100 $\mathrm{g}$ (Table 1). The observed increase for the moisture does not seem to have significantly affected the hygroscopicity. Certainly, a fact to be considered to explain the observed behavior is the presence of maltodrextrin in powder form which is considered to be a substance of low hygroscopicity. Angel et al. (2009) when studying the passion fruit powder obtained by spray drying, observed values of 17.39 to $35.38 \mathrm{~g}$ of absorbed water/100 $\mathrm{g}$ and concluded that the passion fruit powder was more hygroscopic due to the presence of lactose and fructose (main monosaccharide present), present in amorphous state, and is not stable in the normal moisture.

Solubility is one of the most utilized parameters to verify the capacity of a powder to remain in a homogenous mixture with water (VISSOTTO et al., 2006). There was a decrease in the mean values until the last day of storage in the present study, with variation from 81.60 to $75.79 \%$ (Table 2). These results decreased with the storage time, and may have occurred because of the sugar crystallization that occurred due to the relative humidity and the storage temperature. In a comparative analysis, the absorbed moisture was not enough to change the hygroscopicity, but it was enough to promote sugar crystallization which led to a decrease in the solubility of the studied samples. Similar behavior to the present study, but with higher results, was reported by Endo et al. (2007), who observed a reduction in solubility with storage time of 99.15 to $98.61 \%$ in passion fruit powder dried by spray drying stored for 180 days at room temperature. 
Table 2. Mean values \pm standard deviation of solubility, moisture, ash, reducing sugar and total sugar of the stability of passion fruit powder stored at room temperature $\left(25 \pm 2^{\circ} \mathrm{C}\right)$ during 360 days.

\begin{tabular}{cccccc}
\hline $\begin{array}{c}\text { Time } \\
\text { (days) }\end{array}$ & Solubility (\%) & Moisture (\%) & Ash (\%) & $\begin{array}{c}\text { Reducing sugar } \\
(\mathbf{\%})\end{array}$ & Total sugar (\%) \\
\hline 0 & $81.60 \pm 0.07$ & $6.47 \pm 0.75$ & $5.37 \pm 0.61$ & $30.79 \pm 3.60$ & $37.60 \pm 4.06$ \\
30 & $77.64 \pm 0.01$ & $5.70 \pm 0.45$ & $5.62 \pm 0.81$ & $28.30 \pm 2.81$ & $36.01 \pm 3.23$ \\
60 & $77.75 \pm 0.02$ & $5.51 \pm 1.23$ & $5.22 \pm 0.25$ & $27.05 \pm 0.74$ & $28.41 \pm 1.53$ \\
90 & $78.02 \pm 0.02$ & $5.87 \pm 0.35$ & $5.26 \pm 0.41$ & $27.55 \pm 0.65$ & $32.78 \pm 1.72$ \\
120 & $72.29 \pm 0.03$ & $7.41 \pm 0.30$ & $4.85 \pm 0.51$ & $28.45 \pm 1.85$ & $34.36 \pm 1.96$ \\
150 & $75.05 \pm 0.03$ & $7.67 \pm 0.41$ & $5.09 \pm 0.55$ & $29.01 \pm 4.04$ & $34.62 \pm 0.49$ \\
180 & $75.40 \pm 0.01$ & $7.45 \pm 0.64$ & $5.19 \pm 0.62$ & $27.57 \pm 2.74$ & $37.12 \pm 6.91$ \\
210 & $75.49 \pm 0.01$ & $7.34 \pm 0.40$ & $5.33 \pm 0.13$ & $27.71 \pm 3.02$ & $33.50 \pm 4.44$ \\
240 & $75.99 \pm 0.01$ & $7.39 \pm 0.94$ & $4.56 \pm 0.55$ & $30.46 \pm 2.31$ & $34.11 \pm 5.28$ \\
270 & $75.88 \pm 0.01$ & $7.61 \pm 0.55$ & $4.65 \pm 0.14$ & $29.35 \pm 3.86$ & $35.44 \pm 7.54$ \\
300 & $74.99 \pm 0.01$ & $7.11 \pm 0.96$ & $4.64 \pm 0.32$ & $25.36 \pm 2.18$ & $41.74 \pm 5.24$ \\
330 & $75.09 \pm 0.02$ & $7.43 \pm 0.90$ & $4.91 \pm 0.27$ & $26.00 \pm 1.96$ & $36.35 \pm 1.41$ \\
360 & $75.79 \pm 0.02$ & $7.01 \pm 0.33$ & $4.77 \pm 0.56$ & $25.50 \pm 3.68$ & $36.94 \pm 5.58$ \\
\hline Average & 76.07 & 6.92 & 5.03 & 27.93 & 35.30 \\
\hline
\end{tabular}

Source: Elaboration of the authors.

There was an increase in the moisture starting from 90 days of storage until the last day of analysis with mean values of $6.92 \%$ (Table 2 ). The observed increase may be due to the packaging used which may not have provided an effective barrier against the oxygen and water vapor, and due to possible variations in temperature and humidity of the storage place. Angel et al. (2009) analyzed the passion fruit powder obtained by spray drying with different concentrations of lactose and maltodeztrin and observed moisture variation from 2.37 to $9.40 \%$. This variation is desirable, because it is within the range of quality parameters for a powder product to be considered a dry product. The results obtained by Angel et al. (2009) were higher than the results found in the present study.

For the ash quantification a small decrease (from 5.37 to $4.77 \%$ ) was observed in the mean values during the 360 days of storage (Table 2), that can possibly be explained by the increase in the moisture of the samples during the storage or at the time of measurement, where the weight was determined with absorbed water. Higher results were reported by Lima (2007), who studied the passion fruit flour and observed mean values of ash of $7.37 \%$, Ishimoto et al. (2007) who found $7.38 \%$ in the peel of passion fruit and Souza, Ferreira and Vieira (2008) who reported mean values of ash of $8.66 \%$ in the powder of the peel of passion fruit.

For the reducing sugars a decrease was observed during the analyzed time, ranging from 30.79 to $25.50 \%$ (Table 2). This reduction could have been caused by a chemical reaction, possibly by reactions of non-enzymatic browning. According to Pereira, Queiroz and Figueirêdo (2006), the observed decrease could also be caused by the increase in the moisture in the passion fruit powder or by its degradation and/or transformation of reducing sugars in other sugars.

Small oscillations were observed for soluble sugars during the storage time and in the last days of storage the mean value was $36.94 \%$ (Table 2). The oscillation in the values may be due to the instability of the reaction, with the occurrence of degradative and synthesis reactions during the storage. The fact that the product is dried and that maltodrextrin is added to the formulation explains the higher soluble sugars results. 
There was a reduction in mean levels of ascorbic acid in the storage period, decreasing from 16.75 $\mathrm{mg} / 100 \mathrm{~g}$ at the beginning of the analyses to 15.86 $\mathrm{mg} / 100 \mathrm{~g}$ the last day of storage (Table 3 ). The small change in this variable is also related to the type of packaging used which, since it did not completely prevent the access of moisture, contributed to the substantial deterioration in the levels of ascorbic acid.

Table 3. Mean values \pm standard deviation of ascorbic acid, $\beta$-carotene, yellow flavonoids, chlorophyll and total extractable polyphenols (TEP) of passion fruit powder stored at room temperature $\left(25 \pm 2^{\circ} \mathrm{C}\right)$ during 360 days.

\begin{tabular}{cccccc}
\hline $\begin{array}{c}\text { Time } \\
(\mathbf{d a y s})\end{array}$ & $\begin{array}{c}\text { Ascorbic acid } \\
(\mathbf{m g} / \mathbf{1 0 0} \mathbf{g})\end{array}$ & $\begin{array}{c}\boldsymbol{\beta} \text {-carotene } \\
\mathbf{( m g / 1 0 0} \mathbf{g})\end{array}$ & $\begin{array}{c}\text { Yellow } \\
\text { flavonoids } \\
(\mathbf{m g} / \mathbf{1 0 0} \mathbf{g})\end{array}$ & $\begin{array}{c}\text { Chlorophyll } \\
(\mathbf{m g} / \mathbf{1 0 0} \mathbf{g})\end{array}$ & $\begin{array}{c}\text { TEP } \\
(\mathbf{m g} \text { GAE/100 g) }\end{array}$ \\
\hline 0 & $16.75 \pm 0.54$ & $12.75 \pm 3.14$ & $15.31 \pm 1.51$ & $5.75 \pm 0.37$ & $175.61 \pm 7.53$ \\
30 & $18.93 \pm 1.19$ & $9.38 \pm 4.65$ & $15.07 \pm 2.11$ & $5.52 \pm 2.25$ & $197.69 \pm 41.04$ \\
60 & $21.57 \pm 0.58$ & $8.06 \pm 3.20$ & $14.36 \pm 0.70$ & $5.70 \pm 2.45$ & $201.46 \pm 32.54$ \\
90 & $19.03 \pm 1.50$ & $10.03 \pm 4.46$ & $14.18 \pm 1.18$ & $5.36 \pm 2.37$ & $222.51 \pm 31.32$ \\
120 & $17.01 \pm 1.30$ & $10.54 \pm 2.30$ & $16.33 \pm 2.32$ & $6.67 \pm 1.53$ & $186.72 \pm 10.49$ \\
150 & $16.80 \pm 1.12$ & $8.51 \pm 4.11$ & $14.77 \pm 1.28$ & $4.69 \pm 3.51$ & $192.98 \pm 20.43$ \\
180 & $17.13 \pm 0.72$ & $9.44 \pm 3.68$ & $17.61 \pm 1.29$ & $5.58 \pm 3.06$ & $197.47 \pm 25.77$ \\
210 & $17.21 \pm 0.94$ & $6.30 \pm 1.78$ & $13.59 \pm 1.40$ & $5.10 \pm 2.23$ & $181.13 \pm 18.85$ \\
240 & $16.05 \pm 0.94$ & $7.64 \pm 5.75$ & $15.85 \pm 0.82$ & $4.81 \pm 1.75$ & $174.60 \pm 4.47$ \\
270 & $16.83 \pm 1.09$ & $6.98 \pm 3.06$ & $16.93 \pm 0.47$ & $5.41 \pm 1.07$ & $185.78 \pm 16.14$ \\
300 & $16.37 \pm 0.99$ & $6.45 \pm 0.47$ & $16.33 \pm 0.79$ & $6.17 \pm 1.24$ & $207.71 \pm 14.56$ \\
330 & $16.00 \pm 0.97$ & $6.02 \pm 2.14$ & $15.95 \pm 1.21$ & $6.50 \pm 1.43$ & $220.87 \pm 23.48$ \\
360 & $15.86 \pm 0.84$ & $6.50 \pm 1.55$ & $16.12 \pm 1.41$ & $5.96 \pm 0.58$ & $196.17 \pm 19.90$ \\
\hline Average & 17.34 & 8.35 & 15.56 & 5.47 & 195.43 \\
\hline
\end{tabular}

Source: Elaboration of the authors.

For the $\beta$-carotene level, a decrease during the storage was observed, which ranged from 12.75 to $6.5 \mathrm{mg} / 100 \mathrm{~g}$ (Table 3). Carotenoids are susceptible to heat, light and oxygen and can suffer autoxidation which can occur during the processing (POLICARPO et al., 2007).

Small oscillations in the results of the yellow flavonoids were observed and on the last day of storage this value was $16.12 \mathrm{mg} / 100 \mathrm{~g}$ (Table 3).

The total chlorophyll did not change during the storage and the mean value was of $5.47 \mathrm{mg} / 100 \mathrm{~g}$ (Table 3). The presence of the total chlorophyll in passion fruit powder may be due to the use of unripe fruit in the production of this powder.

The total extractable polyphenols presented mean value of $195.43 \mathrm{mg} \mathrm{GAE} / 100 \mathrm{~g}$ (Table 3).
The luminosity increased from 49.01 to 73.34 . It can be explained by the addition of food additives during the powder processing, such as maltrodextrin which has a white color (KHA, NGYEN; ROACH, 2010) or it could be related to the chemical reactions resulting in pigment degradation such as the carotenoid that is responsible for the color of this powder and which can easily be degraded by the action of temperature, acids, oxygen and enzymes and by the interaction with other components such as ascorbic acid, metal ions and sugars.

The a* coordinate did not change during storage, being represented by the mean value of $\hat{y}=-0.84$ which characterizes a color close to greenish yellow. In the study with passion fruit powder produced by atomization, Pedro (2009) observed values ranging from 1.75 to 4.12 for the $\mathrm{a}^{*}$ coordinate, which were higher than the results found in the present study. 
The $b^{*}$ coordinate values presented significance difference $(\mathrm{p} \leq 0.05)$. There was little oscillation for $\mathrm{b}^{*}$ coordinate during storage, indicating a powder discoloration, and at the end of the experiment the means value of this variable was 20.11 , which was higher than the initial value at time 0 (Table 4). According to Barbosa (2010), the decrease in the $b^{*}$ can be due to the presence of heat sensitive reactions involving oxidation of carotenoids, and, depending on the storage temperature and the presence of light, it can result in a powder with less yellow color.

Table 4. Mean values \pm standard deviation of color: $\mathrm{L}^{*}, \mathrm{a}^{*}, \mathrm{~b}^{*}$, chroma and of passion fruit powder stored at room temperature $\left(25 \pm 2^{\circ} \mathrm{C}\right)$ during 360 days.

\begin{tabular}{cccccc}
\hline $\begin{array}{c}\text { Time } \\
\text { (days) }\end{array}$ & $\mathbf{L}^{*}$ & $\mathbf{a}^{*}$ & $\mathbf{b}^{*}$ & Chroma & Hue \\
\hline 0 & $49.01 \pm 1.22$ & $-1.02 \pm 0.10$ & $13.59 \pm 0.44$ & $13.62 \pm 0.45$ & $94.16 \pm 0.12$ \\
30 & $49.94 \pm 0.28$ & $-1.09 \pm 0.16$ & $14.58 \pm 0.40$ & $14.68 \pm 0.40$ & $94.56 \pm 0.38$ \\
60 & $50.00 \pm 1.32$ & $-0.77 \pm 0.27$ & $14.14 \pm 0.42$ & $14.2 \pm 0.49$ & $93.27 \pm 0.89$ \\
90 & $50.65 \pm 5.01$ & $-0.87 \pm 0.20$ & $13.60 \pm 2.07$ & $13.09 \pm 1.87$ & $93.62 \pm 0.37$ \\
120 & $53.37 \pm 4.80$ & $-0.8 \pm 0.27$ & $14.36 \pm 2.29$ & $14.38 \pm 2.30$ & $93.11 \pm 0.80$ \\
150 & $52.64 \pm 0.32$ & $-0.85 \pm 0.11$ & $13.95 \pm 0.84$ & $14.13 \pm 0.56$ & $94.25 \pm 1.38$ \\
180 & $52.49 \pm 7.33$ & $-0.97 \pm 0.48$ & $13.14 \pm 1.00$ & $13.18 \pm 0.97$ & $93.07 \pm 0.55$ \\
210 & $65.73 \pm 14.83$ & $-1.12 \pm 0.34$ & $18.20 \pm 4.98$ & $18.18 \pm 4.87$ & $93.60 \pm 0.22$ \\
240 & $55.49 \pm 7.33$ & $-0.81 \pm 0.27$ & $13.35 \pm 2.80$ & $13.46 \pm 2.60$ & $93.51 \pm 0.51$ \\
270 & $57.72 \pm 3.46$ & $-0.60 \pm 0.51$ & $14.42 \pm 0.87$ & $14.58 \pm 0.55$ & $92.88 \pm 1.31$ \\
300 & $51.85 \pm 6.03$ & $-0.60 \pm 0.51$ & $12.05 \pm 1.04$ & $12.41 \pm 1.33$ & $92.85 \pm 0.91$ \\
330 & $70.54 \pm 8.53$ & $-0.52 \pm 0.87$ & $19.39 \pm 4.16$ & $18.66 \pm 4.53$ & $92.44 \pm 1.23$ \\
360 & $73.34 \pm 9.78$ & $-0.96 \pm 0.52$ & $20.11 \pm 3.65$ & $19.77 \pm 4.11$ & $91.91 \pm 2.12$ \\
\hline Average & 56.36 & -0.84 & 14.99 & 14.94 & 93.32 \\
\hline
\end{tabular}

Source: Elaboration of the authors.

Chroma results presented significance difference $(p \leq 0.05)$ during the storage time. An increase of this variable (Table 4) was found, indicating variation in color saturation during the storage time thus leading to a less yellow powder at the end of the experiment, and this fact is possibly related to the oxidation of passion fruit pigments, which was accelerated by the heat, humidity and oxygen permeability of the packaging.

The Hue angle $\left(\mathrm{h}^{*}\right)$ presented significance difference $(p \leq 0.05)$ during the storage, presenting linear behavior. A decrease of this variable was consequently found during the storage, due to the fact that the oscillatory behavior of $b^{*}$, which results from the degradation of pigments, such as carotenoids, seems to prevail, defining the behavior of the Hue angle. The averages obtained for the $h^{*}$ of passion fruit powder ranged from 94.16 to 91.91 (Table 4).

\section{Microbiological Analysis}

No microbial growth in the passion fruit powder was observed, and all the analyzed variables were in accordance with Resolution RDC n ${ }^{\circ} .12$ of January 02, 2001 from the Secretaria de Vigilância Sanitária (ANVISA, 2001) and with the Portaria $n^{\circ} .451$ of September 19, 1997 (ANVISA, 1997). The coliform at $35^{\circ} \mathrm{C}$ and $45^{\circ} \mathrm{C}$ counts presented values lower than $3 \mathrm{MPN} / \mathrm{g}$ which is lower than that established by the legislation $\left(10^{2} \mathrm{MPN} / \mathrm{g}\right)$ (ANVISA, 2001). 
Until the $120^{\text {th }}$ day of the storage, the presence of mesophilic was of $0.6 \times 10 \mathrm{CFU} / \mathrm{g}$ (Table 5), this fact could be explained due to the initial contamination of raw materials or because of an inadequate cleaning of equipment, tools and manipulators.
These microorganisms appear to have remained viable and able to grow during the storage, when, indeed, due to low water activity of the passion fruit powder, after the $150^{\text {th }}$ day these organisms started to decrease gradually to values less than $10 \mathrm{CFU} / \mathrm{g}$.

Table 5. Microbiological analyzes of passion fruit powder from organic cultivation during 360 days of storage at room temperature $\left(25 \pm 2^{\circ} \mathrm{C}\right)$.

\begin{tabular}{ccccccc}
\hline $\begin{array}{c}\text { Time } \\
(\text { days })\end{array}$ & $\begin{array}{c}\text { Coliforms } \\
\text { at } 35^{\circ} \mathrm{C} \\
(\mathrm{MPN} / \mathrm{g})\end{array}$ & $\begin{array}{c}\text { Coliforms } \\
\text { at } 45^{\circ} \mathrm{C} \\
(\mathrm{MPN} / \mathrm{g})\end{array}$ & $\begin{array}{c}\text { Salmonella } \\
\text { sp/25 g }\end{array}$ & $\begin{array}{c}\text { Mesophilic } \\
(\mathrm{CFU} / \mathrm{g})\end{array}$ & $\begin{array}{c}\text { Staphylococcus } \\
\text { coagulase } \\
\text { positive } \\
(\mathrm{CFU} / \mathrm{g})\end{array}$ & $\begin{array}{c}\text { Yeast/mold } \\
(\mathrm{CFU} / \mathrm{g})\end{array}$ \\
\hline 0 & $<3.0$ & $<3.0$ & Absence & $3.0 \times 10$ & $<10$ & $2.3 \times 10$ \\
30 & $<3.0$ & $<3.0$ & Absence & $2.0 \times 10$ & $<10$ & $1.3 \times 10$ \\
60 & $<3.0$ & $<3.0$ & Absence & $0.5 \times 10$ & $<10$ & $1.6 \times 10$ \\
90 & $<3.0$ & $<3.0$ & Absence & $0.3 \times 10$ & $<10$ & $1.0 \times 10$ \\
120 & $<3.0$ & $<3.0$ & Absence & $0.6 \times 10$ & $<10$ & $0.6 \times 10$ \\
150 & $<3.0$ & $<3.0$ & Absence & $<10$ & $<10$ & $1.6 \times 10$ \\
180 & $<3.0$ & $<3.0$ & Absence & $<10$ & $<10$ & $0.6 \times 10$ \\
210 & $<3.0$ & $<3.0$ & Absence & $<10$ & $<10$ & $0.6 \times 10$ \\
240 & $<3.0$ & $<3.0$ & Absence & $<10$ & $<10$ & $0.3 \times 10$ \\
270 & $<3.0$ & $<3.0$ & Absence & $<10$ & $<10$ & $0.6 \times 10$ \\
300 & $<3.0$ & $<3.0$ & Absence & $<10$ & $<10$ & $0.6 \times 10$ \\
330 & $<3.0$ & $<3.0$ & Absence & $<10$ & $<10$ & $0.3 \times 10$ \\
360 & $<3.0$ & $<3.0$ & Absence & $<10$ & $<10$ & $0.6 \times 10$ \\
\hline
\end{tabular}

${ }^{*} \mathrm{MPN}$ - Most Probable Number/g

${ }^{* *} \mathrm{CFU}$ - Colony Forming Units/g.

Source: Elaboration of the authors.

The Staphylococcus coagulase positive presented values of $<10 \mathrm{CFU} / \mathrm{g}$ during the storage, which the legislation allows until $10^{2} \mathrm{CFU} / \mathrm{g}$. This result was expected because the powder studied presented low acidity and water activity, preventing the growth of these microorganisms. With regard to the yeasts and mold count, the product had a maximum of 2.3 x $10 \mathrm{CFU} / \mathrm{g}$ (Table 5), low values, which do not compromise the microbiological stability of the passion fruit powder analyzed, being determined by the lower Portaria $n^{\circ} .451$ of September 19, 1997 , which is $2.0 \times 10^{3} \mathrm{CFU} / \mathrm{g}$ (ANVISA, 1997).

\section{Conclusion}

The product presented a small decrease in ascorbic acid and titratable acidity, desirable hygroscopicity, low water activity and acid $\mathrm{pH}$ stable, high levels of sugar, ash and total extractable polyphenols.

It was possible to observe an increase in the moisture and a decrease in the solubility during the study period, and it can therefore be concluded that the permeable packaging and storage under ambient temperatures $\left(25 \pm 2{ }^{\circ} \mathrm{C}\right)$ influenced the results for these parameters. The studied product meets the microbiological standards established by Brazilian law, and is suitable for human consumption. 
The organic passion fruit powder remained practically stable in the storage conditions tested, offering great potential for use as an ingredient in different kinds of food.

\section{References}

ANGEL, R. M. C.; MUÑOZ, L. C. E.; AVILES-AVILES, C.; GARCÍA, R. G.; SANTILLÁ, N. M. M.; LAGUNES, A. G.; ARCHILA, M. A. Spray-Drying of passion fruit juice using lactose maltodextrina blends as the support material. Brazilian Archives of Biology and Tecnology, Curitiba, v. 52, n. 4, p. 1011-1018, 2009.

AGÊNCIANACIONAL DE VIGILÂNCIA SANITÁRIA - ANVISA. Divisão Nacional de Vigilância Sanitária de Alimentos. 2007. Portaria $n^{\circ} 451$, de 19 de setembro de 1997.

Agência Nacional de Vigilância Sanitária. Divisão Nacional de Vigilância Sanitária de Alimentos. 2001. Resolução RDC nº 12, de 02 de janeiro de 2001.

ASSOCIATION OF OFFICIAL ANALYTICAL CHEMISTS - AOAC. Official Methods of analysis of the Association of Official Analytical Chemists (method 900.02). Arlington: A.O.A.C., v. 2, 1995, chapter 44, p. 10-12.

AMERICAN PUBLIC HEALTH ASSOCIATION APHA. DOWNES. Compendium of methods for the microbiological examination of foods. Washington DC, $200.676 \mathrm{p}$.

BARBOSA, S. J. Qualidade de suco em pó de mistura de frutas obtido por spray drying. 2010. Dissertação (Mestrado em Produção Vegetal) - Universidade de Montes Claros, Montes Claros.

BEZERRA, T. S. Comportamento higroscópico de pós de diferentes variedades de manga (Mangifera indica L.). 2009. Dissertação (Mestrado em Tecnologia de Alimentos) - Universidade Federal do Ceará, Fortaleza.

BRUINSMA, J. The quantitative analysis of chlorophylls $\mathrm{A}$ and $\mathrm{B}$ in plant extracts. Photochemistry and photobiology, Elmsford, v. 2, n. 2, p. 241-249, 1963.

BUSCH, K.; ZENTEC, J.; WORTMANN, F. J.; BIOURGE, V. UV light, temperature, and humidity effects on white hair color in dogs. The Journal of Nutrition, Bethesda, v. 134, n. 8, p. 2053-2055. 2004.

CANO-CHAUCA, M.; STRINGHETA, P. C.; RAMOS, A. M.; CAL-VIDAL, J. Effect of the carriers on the microstructure of mango power obtained by spray drying and its characterize characterization innovative. Innovative Food Science and Emerging Technologies, Wageningen, v. 6, n. 4, p. 420-428. 2005.

CANTERI, M. H. G.; SCHEER, A. P.; WOSIACKI, G.; GINIES, C.; REICH, M.; RENARD, C. M. C. G. A comparative study of pectin extracted from passion fruit. Journal of Polymers and the Environment, New York, v. 18, n. 4, p. 593-599, 2010.

ENDO, E.; BORGES, S. V.; DAIUTO, E. R.; CEREDA, M. P.; AMORIM, E. Avaliação da vida de prateleira do suco de maracujá (Passiflora edullis f. flavicarpa) desidratado. Ciência e Tecnologia de Alimentos, Campinas, v. 27, n. 2, p. 382-386, 2007.

ENGEL, V. L.; POGGIANI, F. Estudo da concentração de clorofila nas folhas e s eu espectro de absorção de luz em função sombreamento em mudas de quatro espécies florestais. Revista Brasileira de Fisiologia Vegetal, Campinas, v. 3, n. 1, p. 39-45, 1991.

FRANCIS, F. J. Analysis of anthocyanins. In: MARKAKIS. P. (Ed.). Anthocyanins as food colors. New York: Academic Press, 1982. p. 181-207.

INSTITUTO ADOLFO LUTZ - IAL. Métodos fisicoquímicos para análise de alimentos. Coordenadores Odair Zenebon. Neus Sadocco Pascuet e Paulo Tiglea. São Paulo: Instituto Adolfo Lutz, 2008. 1020 p.

ISHIMOTO, F. Y.; HARADA, A. I.; BRANCO, I. G.; CONCEIÇÃO, W. A. S.; COUTINHO, M. R. Aproveitamento alternativo da casca do maracujáamarelo (Passiflora edulis f. var. flavicarpa Deg.) para produção de biscoitos. Revista Ciências Exatas e Naturais, Guarapuava, v. 9, n. 2, p. 279-292, 2007.

KHA, T. C.; NGYEN, M. H.; ROACH, P. D. Effects of spray drying conditions on the physicochemical and antioxidant properties of Gac (Momordica cochinchinensis) fruit aril powder. Journal of Food Engineering, Ontario, v. 98, n. 3, p. 385-392, 2010.

KISHORE, K.; PATHAK, K. A.; SHUKLA, R.; BHAR, R. Effect of storage temperature on physico-chemical and sensory attributes of purple passion fruit (Passiflora edulis Sims). Journal of Food Science and Technology, London, v. 48, n. 4, p. 484-488, 2011.

LARRAURI, J. A.; RUPÉREZ, P.; SAURA-CALIXTO, F. Effect of drying temperature on the stability of polyphenols and antioxidant activity of red grape pomace peels. Journal of Agricultural and Food Chemistry, Davis, v. 45, n. 4, p. 1390-1393, 1997. 
LIMA, C. C. Aplicação das farinhas de linhaça (Linum usitatissimum L.) e maracujá (Passiflora edulis Sims f. flavicarpa Deg.) no processamento de pães com propriedades funcionais. 2007. Dissertação (Mestrado Ciências e Tecnologia de Alimentos) - Universidade Federal do Ceará, Fortaleza.

MILLER, G. L. Use of dinitrosalicilic acid reagent for determination of reducing sugar. Analytical Biochemistry, New York, v. 31, n. 3, p. 426-428, 1959.

MOURA, S. M. Estabilidade de acerola em pó oriunda de cultivo orgânico. 2010. Dissertação (Mestrado em Ciências e Tecnologia de Alimentos) - Universidade Federal do Ceará, Fortaleza.

NAGATA, M.; YAMASHITA, I. Simple method for simultaneous determination of chlorophyll and carotenoids in tomato fruit. Journal of the Japanese Society for Food Science and Technology, Oxford, v. 39, n. 10, p. 925-928, 1992.

OLIVEIRA, A. R. G.; BORGES, S. V.; FARIA, R. K.; GREGÓRIO, E. E. S. R. Influência das condições de secagem por atomização sobre as características sensoriais de sucos maracujá (passiflora edullis) e abacaxi (harac comosus) desidratados. Revista Ciência Agronômica, Fortaleza, v. 38, n. 3, p. 251-256, 2007.

OLIVEIRA, V. S.; AFONSO, M. R. A.; COSTA, J. M. C. Caracterização físico-química e comportamento higroscópico de sapoti liofilizado. Revista Ciência Agronômica, Fortaleza, v. 42, n. 2, p. 342-348, 2011.

PAGLIARINI, M. F. Efeito da adubação orgânica na produção e qualidade de frutos de maracujazeiro amarelo (Passiflora edulis, Sims f. flavicarpa degener). 2006. Dissertação (mestrado em Produção Vegetal) Universidade Federal de Viçosa, Viçosa.

PEDRO, M. A. M. Influencia de encapsulantes e do método de secagem nas propriedades fisico-químicas e atributos de qualidade de polpa de maracujá em pó. 2009. Tese (doutorado em biociências) - Universidade Estadual Paulista, São José do Rio Preto.

PEREIRA, I. E.; QUEIROZ, A. J. M.; FIGUEIRÊDO, R. M. F. Características físico-químicas do tomate em pó durante o armazenamento. Revista de Biologia e Ciências da Terra, João Pessoa, v. 6, n. 1, p. 83-90, 2006.
POLICARPO, V. M. N.; BORGES, S. V.; ENDO, É.; DE CASTRO, F. T.; DAMICO, A. A.; CAVALCANTI, N. B. Estabilidade da cor de doces em massa de polpa de umbu (Spondias tuberosa arr. Cam.) no estádio de maturação verde. Ciência e Agrotecnologia, Lavras, v. 31, n. 4, p. 1102-1107, 2007.

PRADO, A. Composiçãofenólica e atividade antioxidante de frutas tropicais. 2009. Dissertação (Mestrado em Ciências e Tecnologia de Alimentos) - Escola Superior de Agricultura Luiz de Queiroz, Piracicaba.

QUEK, S. Y.; CHOK, N. K.; SWEDLUND, P. The physicochemical properties of spray-dried watermelon powders. Chemical Engineering and Processing: Process Intensification, Auckland, v. 46, n. 5, p. 386-392, 2007.

SAS INSTITUTE. Inc. SAS User's Guide: version 9.1. Cary. NC: SAS Institute. 2006.

SOUZA, M. W. S.; FERREIRA, T. B. O.; VIEIRA, I. F. R. Composição centesimal e propriedades funcionais tecnológicas da farinha da casca do maracujá. Alimentos e Nutrição, Araraquara, v. 19, n. 1, p. 33-36, 2008.

UCHOA, A. M. A.; COSTA, J. M. C.; MAIA, G. A.; SILVA, E. M. C.; CARVALHO, A. F. F. U.; MEIRA, T. R. Parâmetros físico-químicos, teor de fibra bruta e alimentar de pós alimentícios obtidos de resíduos de frutas tropicais. Revista Segurança Alimentar e Nutricional, Campinas, v. 15, n. 2, p. 58-65, 2008.

VIEIRA, H.; FIGUEIRÊDO, R. M. F.; QUEIROZ, A. J. M. Isotermas de adsorção de umidade da pitanga em pó. Revista de Biologia e Ciências da Terra, João Pessoa, v. 7, n. 1, p. 11-20, 2007.

VISSOTTO, F. Z.; MONTENEGRO, F. M.; SANTOS, J. M.; OLIVEIRA, S. J. R. Avaliação da influência dos processos de lecitinação e de aglomeração nas propriedades físicas de achocolatado em pó. Ciência e Tecnologia de Alimentos, Campinas, v. 26, n. 3, p. 666671, 2006.

YEMN, E. W.; WILLIS, A. J. The estimation of carbohydrate in plant extracts by anthrone. Biochemical Journal, London, v. 57, n. 3, p. 508-14, 1954. 